\title{
Comparison Between The Position Of Adopted Children In Islamic Law Inheritance Based On Islamic Law Compilation (KHI) With The Book Of Civil Law
}

\author{
Agil Aladdin ${ }^{\mathbf{1}}$ and Akhmad Khisni ${ }^{2}$
}

\begin{abstract}
This research aims to knowing position adopted child in Islamic Law Compilation with the Book of Civil Law; and Similarities and Differences position adopted children in inheritance of Islamic Law Compilation with the Book of Civil Law; This research method using normative juridical research with comparative approach (comparative). The results were obtained conclusions from Islamic Law Compilation in terms of inheritance, uninterrupted lineage adopted children with biological parents, who turned just the responsibility of the biological parents to the adoptive parents. The adopted child does not become heir of adopted parents. In Gazette No. 129 Of 1917. In Article 5 through Article 15. The position adopted child found in Article 12 to equate a child with a legitimate child of the marriage of the lift. According to the Civil Law for the adopted child the same as for biological children. While in KHI adopted children get as much as $1 / 3$ of the estate left by his adoptive parents (Article $209 \mathrm{KHI}$ ) exception has been assigned the consent of all the heirs.

Keywords: Heritage; Adopted; Testament.
\end{abstract}

\section{Introduction}

In a marriage between husband and wife are expected to get a good descent and is a beacon of hope for both parents. The presence of children is a form of continuity of a family and the offspring as an investment in the future, but a marriage will be is not yet complete when the couple no children.

Opinion Mudaris Zaini said that the desire to have a child is a human instinct, it is in line with the innate nature of human nature who felt that the child part of flesh and blood parents, who also will inherit also the special qualities of both parents. ${ }^{3}$

A new family is said to be complete if it consists of a father, mother and child. Adoption usually occurs when couples have not or have no children. To overcome that desire to have a child one way to do is to adopt a child or adoption.

In this case the adoption is set in law, based on Article 1 paragraph 2 Government Regulation No. 54 Of 2007 on the Implementation of the Adoption (PP 54/2007):

"A legal act which distract a child from the environment of its parents, legal guardian, or other person responsible for the care, education and parenting, into a family environment with foster parents."

Basically, adoptions aimed at the best interests of the child in order to realize the child welfare and protection of children, which is implemented based on local custom and the provisions of the legislation (Article 2 of Regulation 54/2007).

Understanding the general adoption is an act of taking someone else's child under the provisions of law applicable in the relevant community. Meanwhile, according to deeds Supomo adopt a child are: ${ }^{4}$ In Indonesia, inheritance law enacted three systems

\footnotetext{
${ }^{1}$ Student Master of Notary, Faculty of Law, Sultan Agung Islamic University Semarang E-mail: rzkfzna@gmail.com

2 Faculty of Law Universitas Islam Sultan Agung

3 Mudaris Zaini, 1992, Adopsi Suatu Tinjauan Dari Tiga Sistem Hukum, Sinar Grafika, Jakarta, p 1.

${ }^{4}$ R. Soepomo, 2000, Bab-bab Tentang Hukum Adat, Pradnya Paramita, Jakarta, p. 103.
} 
namely the Civil inheritance law, Islam, and Indigenous. The third legal system is in force because it has no legislation national inheritance laws to govern all the people of Indonesia.

Adoption aims to continue the descent when a marriage is not procreation, maintaining the bond of marriage, and not infrequently because of social, economic, cultural and political. But the position adopted children of inheritance to be provided by the adoptive parents there is a difference according to the Book of Civil Law and Islamic Law Compilation (KHI).

Adoption or adoption of a child are not regulated in the Civil Law, it set out in Chapter XII of Book I of Part 3 of Article 280 to Article 289 of the children outside of marriage. Recognition of children as happened in practice in the world community and justice now, not only limited recognition outside of mating child, but already includes the recognition of a child in a broad sense. Thus, "the actual Civil Law does not regulate the adoption of children as it is known today. ${ }^{5}$

In the Civil Law there is no term adopted child or foster child. Arrangements regarding the adopted child can only be found in the Gazette Of 1917 No. 129 of 1917 which is a complement of the Civil Law, as in the Civil Law there are no rules governing the adopted child, the birth of the Statute is to complete the legal void concerning issues the. Regulation has become a reference for adoption or adoption of a child to people who are subject to the Civil Law (Burgerlijk Weetboek). In this Statute states that adopted children have a legal and civil relations equated his position as a child born of his adoptive parents, so made as children born from the marriage of the adoptive parents and heirs of the adoptive parents. ${ }^{6}$

Muhammadiyah and NU's fatwa concerning adoption that: An adopted child should not be recognized and equated as biological children, resulting in the division of inheritance, adopted children who do not have a relationship lineage or blood relationship with his adoptive parents can not inherit each other. In other words, the adopted child does not inherit the estate left by his adoptive parents, and vice versa adoptive parents do not inherit the legacy of his adopted child. ${ }^{7}$

For the sake of justice and the welfare of adopted children then KHI through Presidential Decree No. 1 of 1991 to allow adopted children inherit his adoptive parents through was borrowed (Article $209 \mathrm{KHI}$ ).

Based on the background of the above problems, the authors are interested in comparing the Civil Law (BW) and KHI in terms of inheritance on the status of the adopted child in a family with the title "Comparison Between The Position Of Adopted Children In Islamic Law Inheritance Based On Islamic Law Compilation (KHI) With The Book Of Civil Law".

Based on the background that has been said above, the authors formulate some problems as follows: The position of the adopted child in Islamic Law Compilation with the Book of Civil Law? How Similarities and Differences position adopted children in inheritance of Islamic Law Compilation with the Book of Civil Law?

Based on the description that has been presented in the above problems, the purpose of this research is: To identify and explain position adopted children in Islamic inheritance of Islamic Law Compilation with the Book of Civil law; and To identify and

\footnotetext{
${ }^{5}$ R. Soeroso, 2007, Perbandingan KUH Perdata, Sinar Grafika, Jakarta, p. 174

${ }^{6}$ Rachmad Budiono, 1999, Pembaharuan Hukum Kewarisan Islam Di Indonesia, Cetakan

Pertama, PT. Citra Aditya Bakti, Bandung, p. 190

7 Wasiun Mika, Kedudukan Hukum dan Hak Waris Anak Angkat (Anak Pungut,Adopsi), http://www.jadipintar.com/2013/08/Kedudukan-Hukum-dan-Hak-Waris-Anak-angkat-Anak-

Pungut-Adopsi.html
} 
explain the comparison position adopted children in Islamic inheritance of Islamic Law Compilation with the Book of Civil law.

\section{Research methods}

This research method using normative juridical research with comparative approach. Normative research is a research method that refers to the legal norms contained in the legislation and the approach taken by the primary legal materials by means of studying the theories, concepts, principles of law as well as legislation related to this research.

\section{Results And Discussion}

\subsection{Position adopted child in Islamic Law Compilation with the Book of Civil Law.}

\subsubsection{Position Adopted According to the Civil Law}

Adoption definition contained in Government Regulation No. 54 of 2007 Article 1 paragraph 2 of Adoption, reads: Adoption is a legal act which distract a child from the environment of its parents, a legal guardian or other person responsible for the care, education and raising children into the family environment adoptive parents.

In Indonesia, inheritance law enacted three systems namely the Civil inheritance law, Islam, and Indigenous. The third legal system is in force because it has no legislation national inheritance laws to govern all the people of Indonesia.

In the Civil Law (BW) does not regulate this child. In the matter of appointment brings due to no adoption is based on the Civil Law. However, due to World War II in the Netherlands has been born of the Law on Adoption, namely: Government Gazette No. 129 of 1917.

In this Statute states that adopted children have a legal and civil relations equated posisisnya as a child born of his adoptive parents, so made as children born from the marriage of the adoptive parents and heirs of the adoptive parents. ${ }^{8}$

Issues regarding adoption or adoption of a child are not regulated in the Civil Law, it set out in Chapter XII of Book I of Part 3 of Article 280 to Article 289 of the children outside of marriage. Recognition of children as happened in practice in the world community and justice now, not only limited recognition outside of mating child, but already includes the recognition of a child in a broad sense. Thus, "the actual Civil Law does not regulate the adoption of children as it is known today". ${ }^{\prime}$

In the Civil Law there is no term adopted child or foster child. Arrangements regarding the adopted child can only be found in the Gazette Of 1917 No. 129 of 1917 which is a complement of the Civil Law, as in the Civil Law there are no rules governing the adopted child, the birth of the Statute is to complete the legal void concerning issues the. Regulation has become a reference for adoption or adoption of a child to people who are subject to the Civil Law (Burgerlijk Weetboek). As for adoption set out in the provisions of the Statute is applicable only for the Chinese community.

Gazette No. 129 of 1917. In Article 5 through Article 15. The position adopted child found in Article 12 to equate a child with a legitimate child of the marriage of the lift.

\footnotetext{
${ }^{8}$ Rachmat Boediono, 1999, Islamic Inheritance Law Reform In Indonesia, First Edition, PT. Citra Aditya Bakti, Bandung, p. 190.

${ }^{9}$ R. Soeroso, 2007, Comparison of the Civil Code, Sinar Grafika, Jakarta, p. 174
} 
Thus, the adopted child in the family has the same status as biological children or children born of his adoptive parents. It, too, resulted in the equal rights and liabilities held by the foster child, including the division of property inheritance if the adoptive parents died. The provisions contained in the Statute No. 129 of 1917 which is a complement of the Civil Law, as in the Civil Law there are no rules governing the foster child.

\subsubsection{Position Adopted According to Islamic Law Compilation (KHI)}

Position adopted children according to Islamic Law Compilation in terms of inheritance, uninterrupted lineage adopted child with his biological parents, who turned just the responsibility of the biological parents to the adoptive parents. The adopted child does not become the heir of his adoptive parents. Adopted children an inheritance only adoptive parents through that amount was borrowed can not exceed $1 / 3$ part of the estate of his adoptive parents.

In the system of the division of inheritance according to Islamic Law Compilation, which in Islamic law, heirs can basically be grouped into three (3) parts, namely: (1) Ashabul furudh, (2) Ashabah, and (3) Dzawil Arham.

In KHI contains a provision concerning the grouping heir stipulated in Article $174 \mathrm{KHI}$, namely: 1) Group heir consists of: According to the blood relations: a) Male group consisting of father, son, brother, uncle, and grandfather, and b) Female group consisting of mother, daughter, sister, and grandmother; 2) According to the marital relationship consists of a widow or widower. If all the heirs exist, then who is entitled to inherit only: children, father, mother, widow or widower.

The position of adopted children by $\mathrm{KHI}$ is fixed as a legitimate child under a court decision not to sever ties with lineage or blood with his biological parents.

\subsection{Similarities and Differences Position adopted child in Islamic Law Compilation with the Book of Civil Law.}

In Islamic Law Compilation and the Civil Law, the same does allow adoption. In the case of adoptive parents died, the boy adopted both by the Islamic Law Compilation and according to civil law equally to an inheritance from his adoptive parents.

Table Similarities and Differences Position adopted child in Islamic Law Compilation with the Book of Civil law

\begin{tabular}{ccc}
\hline No & \multicolumn{1}{c}{ Equation } & \multicolumn{1}{c}{ Difference } \\
\hline 1 & Article 1100 of the Civil Law and & In the Civil Law adopted child status \\
Article $175 \mathrm{KHI}$ equally related & equated with biological children, while in \\
to debt payments heir, & the Islamic Law Compilation expressly sets \\
performing wills, inheritance, & it apart. This was due to the adoption in \\
and other expenses. & $\begin{array}{l}\text { lineage KHI not to sever ties between the } \\
\text { adopted child with his biological parents. }\end{array}$ \\
\hline
\end{tabular}


2 Settings on Article 838 of the Civil Law and Article $173 \mathrm{KHI}$ relating to matters that hinder heir to inherit, such as their verdict finalized, convicted have been blamed for killing heir, defamatory heir, or persecute heir, commit a crime against himself heir punishable by 5 years imprisonment or more severe.
In the system of the division of inheritance according to the Civil Law, the heirs are divided into four groups. As the adopted child of his legacy division equated with the biological children adopted children belonging to the heirs of the first group consisting of children or all descendants, spouses who live the longest. While in the Islamic law, the adopted child does not fall within the category heirs are divided into three groups, namely: Ashabul furudh, Ashabah, and Dzawil Arham. Foster child in Article $174 \mathrm{KHI}$ is also not included in the group of heirs. To address these conditions, the adopted child can earn a share of inheritance through was borrowed under Article 209 KHI. child the same as for biological children. While in KHI adopted children get as much as $1 / 3$ of the estate left by his adoptive parents (Article $209 \mathrm{KHI}$ ) exception has been assigned the consent of all the heirs.

\section{Closing}

\subsection{Conclusion}

- Position adopted children between the Islamic inheritance of Islamic Law Compilation with the Book of Civil Law is:

Islamic Law Compilation in terms of inheritance, uninterrupted lineage adopted children with biological parents, who turned just the responsibility of the biological parents to the adoptive parents. The adopted child does not become the heir of his adoptive parents. Adopted children an inheritance only adoptive parents through that amount was borrowed can not exceed $1 / 3$ part of the estate of his adoptive parents.

In the Civil Law there is no term adopted child or foster child. Arrangements regarding the adopted child can only be found in the Gazette Of 1917 No. 129 of 1917 which is a complement of the Civil Law, as in the Civil Law there are no rules governing the adopted child, the birth of the Statute is to complete the legal void concerning issues the. Regulation has become a reference for adoption or adoption of a child to people who are subject to the Civil Law (Burgerlijk Weetboek). As for adoption set out in the provisions of the Statute is applicable only for the Chinese community.

Gazette No. 129 of 1917. In Article 5 through Article 15. The position adopted child found in Article 12 to equate a child with a legitimate child of the marriage of the lift.

Thus, the adopted child in the family has the same status as biological children or children born of his adoptive parents. It, too, resulted in the equal rights and liabilities held by the foster child, including the division of property inheritance if the 
adoptive parents died. The provisions contained in the Statute No. 129 of 1917 which is a complement of the Civil Law, as in the Civil Law there are no rules governing the foster child.

- Similarities and Differences Position adopted children in inheritance of Islamic Law Compilation with the Book of Civil Law is:

- The equation is: a) Article 1100 of the Civil Law and Article $175 \mathrm{KHI}$ related to debt payments heir, performing wills, inheritance, and other expenses; b). Settings on Article 838 of the Civil Law and Article $173 \mathrm{KHI}$ relating to matters that hinder heir to inherit, such as their verdict finalized, convicted have been blamed for killing heir, defamatory heir, or persecute heir, commit a crime against himself heir punishable by 5 years imprisonment or more severe.

- The difference is: a. In the Civil Law adopted child status equated with biological children, while in the Islamic Law Compilation expressly sets it apart. This was due to the adoption in lineage KHI not to sever ties between the adopted child with his biological parents; b. In the system of division of inheritance according to the Civil Law, the division of inheritance As adopted children equated with biological children. While in the Islamic law, the adopted child does not fall within the category heir; c. According to the Civil Law for the adopted child the same as for biological children. While in KHI adopted children get as much as $1 / 3$ of the estate left by his adoptive parents (Article $209 \mathrm{KHI}$ ) exception has been assigned the consent of all the heirs.

\subsection{Suggestion}

- Suggested the government should immediately realize the Law of adoption are complete and in line with the interests of the people of Indonesia in connection with the inheritance for adopted children.

- Suggested to people who embraced Islam when in lifting children must be guided by the Islamic Law Compilation.

\section{Bibliography}

Books

[1] Mudaris Zaini, 1992, Adopsi Suatu Tinjauan Dari Tiga Sistem Hukum, Sinar Grafika, Jakarta.

[2] R. Soepomo, 2000, Bab-bab Tentang Hukum Adat, Pradnya Paramita, Jakarta.

[3] R. Soeroso, 2007, Perbandingan KUH Perdata, Sinar Grafika, Jakarta.

[4] Rachmad Budiono, 1999, Pembaharuan Hukum Kewarisan Islam Di Indonesia, Cetakan Pertama, PT. Citra Aditya Bakti, Bandung.

Legislation

[1] Article 209 of the Islamic Law Compilation on Wajibah Testament.

[2] Statute No. 129 Of 1917 on Adoption child.

[3] Book of Civil law

Internet

[1] Wasiun Mika, Kedudukan Hukum dan Hak Waris Anak Angkat (Anak Pungut, Adopsi), http://www.jadipintar.com/2013/08/Kedudukan-Hukum-dan-Hak-WarisAnak-angkat-Anak-Pungut-Adopsi.html 